\title{
EFISIENSI MODAL KERJA, LIKUIDITAS DAN SOLVABILITAS PENGARUHNYA TERHADAP PROFITABILITAS PADA PERUSAHAAN-PERUSAHAAN YANG TERDAFTAR DI BURSA EFEK INDONESIA PERIODE 2010 - 2015
}

\author{
Sukma Irdiana \\ Program Studi Manajemen, STIE Widya Gama Lumajang \\ Irdiana pasah77@yahoo.com
}

\begin{abstract}
An enterprise must have desire to acquire profitability high .For that companies should be able to manage efficiency working capital, liquidity and solvabilitasnya. This study attempts to know how big the influence of efficiency working capital, liquidity and solvability to profitability in companies listed at the indonesian stock exchange. Sample selection is based on a method of purposive sampling. Lab data is obtained from secondary data of financial report. This study will uses the multiple regression data this research mixed with on the spss 16.0. The findings from the study in partial shows that efficiency working capital (WCT) have no influence very significant to profitability. But liquidity (CR) and solvability (DER) having influence very significant to profitability. While simultaneously show efficiency working capital (WCT), liquidity (CR) and solvability (DER) having influence very significant to profitability.
\end{abstract}

Keywords : Efficiency Working Capital , Liquidity, Solvability and Profitability.

Abstrak. Suatu perusahaan pasti memiliki keinginan untuk memperoleh profitabilitas yang tinggi. Untuk itu perusahaan harus dapat mengelola efisiensi modal kerja, likuiditas dan solvabilitasnya. Penelitian ini bertujuan untuk mengetahui seberapa besar pengaruh efisiensi modal kerja, likuiditas dan solvabilitas terhadap profitabilitas pada perusahaan-perusahaan yang terdaftar di Bursa Efek Indonesia. Pemilihan sampel dilakukan berdasarkan metode Purposive Sampling. Data penelitian ini diperoleh dari data sekunder berupa laporan keuangan. Penelitian ini akan menggunakan metode Multiple Regression Data penelitian ini diolah dengan menggunakan program SPSS 16.0. Temuan dari penelitian ini secara parsial menunjukkan bahwa efisiensi modal kerja (WCT) tidak memiliki pengaruh yang sangat signifikan terhadap profitabilitas. Namun likuiditas (Current Rasio) dan solvabilitas (DER) memiliki pengaruh yang sangat signifikan terhadap profitabilitas. Sedangkan secara simultan menunjukkan efisiensi modal kerja (WCT), likuiditas (Current Rasio) dan Solvabilitas (DER) memiliki pengaruh yang sangat signifikan terhadap profitabilitas.

\section{Kata Kunci : Efisiensi Modal Kerja, Likuiditas, Solvabilitas dan Profitabilitas}

\section{PENDAHULUAN}

Suatu perusahaan pasti menginginkan profitabilitas yang tinggi. Untuk itu perusahaan harus menjaga profitabilitasnya tetap stabil. Sehingga tujuan perusahaan untuk mencapai profitabilitas yang optimal dapat tercapai. Profitabilitas dapat memberikan petunjuk yang berguna dalam menilai keefektivan dari operasi sebuah perusahaan, sehingga rasio profitabilitas akan menunjukan kombinasi dari efek likuiditas, manajemen aktiva, dan utang pada hasil-hasil operasi. Salah satu kebijakan keuangan yang mempengaruhi kemampuan perusahaan mendapatkan keuntungan adalah masalah efisiensi modal kerja. Efisiensi juga dapat disebut sebagai daya guna dimana penekanannya disamping hasil yang ingin dicapai, juga memperhitungkan pengorbanan untuk mencapai hasil. 
Perusahaan ketika memutuskan dan menetapkan modal kerja dalam jumlah yang besar, maka semakin besar tingkat likuiditas perusahaan, begitu juga sebaliknya untuk hal-hal yang lainnya. Dengan tingkat likuiditas yang lebih besar, risiko semakin kecil, namun kesempatan untuk memperoleh laba yang besar akan menurun yang pada akhirnya berdampak pada menurunnya profitabilitas. Sebaliknya jika perusahaan ingin memaksimalkan profitabilitas, kemungkinan dapat mempengaruhi tingkat likuiditas perusahaan. Makin tinggi likuiditas, maka makin baiklah posisi perusahaan di mata kreditur. Oleh karena terdapat kemungkinan yang lebih besar bahwa perusahaan akan dapat membayar kewajibannya tepat pada waktunya. Di lain pihak ditinjau dari segi sudut pemegang saham, likuiditas yang tinggi tidak selalu menguntungkan karena berpeluang menimbulkan dana-dana yang menganggur yang sebenarnya dapat digunakan untuk berinvestasi dalam proyek-proyek yang menguntungkan perusahaan. Selain masalah tersebut di atas perusahaan juga dihadapkan pada masalah penentuan sumber dana. Pemenuhan kebutuhan dana suatu perusahaan dapat dipenuhi dari sumber intern perusahaan, yaitu dengan mengusahakan penarikan modal melalui penjualan saham kepada masyarakat atau laba ditahan yang tidak dibagi dan digunakan kembali sebagai modal. Pemenuhan kebutuhan dana perusahaan dapat juga dipenuhi dari sumber ekstern yaitu dengan meminjam dana kepada pihak kreditur seperti bank, lembaga keuangan bukan bank, atau dapat pula perusahaan menerbitkan obligasi untuk ditawarkan kepada masyarakat.

Namun jika perusahaan menggunakan lebih banyak hutang sebagai sumber pendanaannya, maka beban bunga yang harus di tanggung juga meningkat. Pada dasarnya, jika perusahaan meningkatkan jumlah hutang sebagai sumber dananya hal tersebut akan meningkatkan risiko keuangan dan perusahaan akan mendapatkan kesempatan mendapatkan laba yang lebih besar. Akan tetapi, jika perusahaan tidak dapat mengelola dana yang diperoleh dari hutang secara produktif, hal tersebut dapat memberikan pengaruh negatif dan berdampak terhadap menurunnya profitabilitas perusahaan. Sebaliknya jika hutang tersebut dapat dikelola dengan baik dan digunakan untuk proyek investasi yang produktif, hal tersebut dapat memberikan pengaruh yang positif dan berdampak terhadap peningkatan profitabilitas perusahaan. Untuk itu penelitian ini dilakukan pada perusahaan-perusahaan yang terdaftar di Bursa Efek Indonesia tepatnya pada perusahaan-perusahaan yang termasuk kedalam saham Blue Chips. Periode pengamatan pada penelitian ini, mulai tahun $2010-2015$.

Berdasarkan latar belakang diatas maka peneliti merumuskan masalah sebagai berikut : 1) Apakah terdapat pengaruh efisiensi modal kerja, likuiditas dan solvabilitas yang signifikan secara parsial terhadap profitabilitas?, 2) Apakah terdapat pengaruh efisiensi modal kerja, likuiditas, dan solvabilitas yang signifikan secara simultan terhadap profitabilitas?

\section{KAJIAN TEORI \\ Manajemen Keuangan}

Manajemen keuangan merupakan kegiatan perencanaan, penerapan dan pengendalian dari : pemanfaatan (pengalokasian) dana, pencarian dana dan pendistribusian laba. Dapat dikatakan bahwa manajemen keuangan adalah aktivitas perusahaan untuk memperoleh dana dan menggunakan dana tersebut secara efisien dalam mencapai tujuan perusahaan. Selain menyangkut aktivitas perusahaan dalam memperoleh dana, manajemen keuangan juga merujuk kepada kemampuan dalam mengelola keuangan di dalam perusahaan, mengefisiensikan dana sehingga tercapai keseimbangan antara pengeluaran dan pendapatan perusahaan yang pada akhirnya akan berdampak baik kepada keuntungan perusahaan (Wibisono, 1997:5).

\section{Modal Kerja}

Modal kerja merupakan sejumlah dana yang selalu tersedia dalam perusahaan yang digunakan untuk membelanjai kegiatan perusahaan. Kegiatan perusahaan ini dapat dimulai jika 
telah tersedia dana yang telah dikeluarkan dan dapat diterima kembali dalam jangka waktu satu tahun.

Pengelolaan modal kerja merupakan hal yang sangat penting agar kelangsungan usaha sebuah perusahaan dapat dipertahanka (Hanafi, 2005:125 dalam Ekadini, 2010). Kesalahan atau kekeliruan dalam pengelolaan modal kerja akan menyebabkan buruknya kondisi keuangan perusahaan sehingga kegiatan perusahaan dapat terhambat atau terhenti sama sekali.

Pembiayaan modal kerja biasanya untuk mendukung penjualan. Banyak perusahaan yang menetapkan aktiva lancar sesuai dengan proporsi penjualan tahunannya. Fluktuasi musiman akan permintaan untuk produk atau jasa perusahaan merupakan faktor penentu besarnya modal kerja. Adanya tren produk tertentu pada waktu tertentu menyebabkan permintaan akan barang atau jasa meningkat sehingga diperlukan modal kerja yang tinggi. Perubahan teknologi yang tentu saja berdampak pada proses produksi dapat mempunyai pengaruh kuat pada kebutuhan terhadap modal kerja. Pada proses produksi konvensional yang biasanya dikerjakan oleh tenaga manusia kemudian digantikan oleh mesin dapat mengurangi pengeluaran terhadap pekerja yang akhirnya akan mengurangi kebutuhan modal kerja. Kebijakan perusahaan akan berdampak pada tingkat modal kerja permanen maupun musiman, misalnya ada kebijakan penghematan yang ditekankan oleh manajemen baru.

Dengan jumlah pengeluaran setiap harinya yang tetap, tetapi dengan makin lamanya periode perputarannya, maka jumlah modal kerja yang dibutuhkan adalah makin besar.Demikian pula halnya dengan periode perputaran yang tetap, dengan makin besarnya jumlah pengeluaran kas setiap harinya, kebutuhan modal kerjapun makin besar. Periode perputaran atau periode terikatnya modal kerja adalah merupakan keseluruhan atau jumlah dari periode-periode yang meliputi jangka waktu pemberian kredit beli, lama penyimpanan bahan mentah di gudang, lamanya proses produksi, lamanya barang jadi disimpan di gudang dan jangka waktu penerimaan piutang.

Kesimpulannya, penggunaan modal kerja secara garis besar ditentukan oleh faktor dari dalam maupun luar perusahaan. Dimana faktor internal menyangkut hal yang berkaitan dengan proses produksi sementara faktor eksternal dipengaruhi oleh keadaan perekonomian dan pasar (Ekadini, 2010:21).

\section{Efisiensi Modal Kerja}

Efisiensi modal kerja adalah pemanfaatan modal kerja aktivitas operasional perusahaan secara optimal sehingga mampu meningkatkan kemakmuran perusahaan itu sendiri. Penggunaan modal kerja akan dinyatakan optimal jika jumlah modal kerja yang digunakan dalam perusahaan mampu menghasilkan keuntungan yang besar pula bagi perusahaan.

Efisiensi modal kerja ini menunjukkan prestasi manajemen dalam mengelola sumber daya perusahaan secara optimal. Semakin efisien penggunaan modal kerja maka semakin baik kinerja manajemen perusahaan. Efisiensi dalam pengelolaan modal kerja juga sangat diperlukan untuk menjamin kelangsungan atau keberhasilan jangka panjang dalam mencapai tujuan perusahaan secara keseluruhan.

Untuk menghitung efisiensi modal kerja dapat menggunakan Working Capital Turnover. Dimana Working Capital Turnover adalah rasio untuk menunjukkan banyaknya penjualan (dalam rupiah) yang dapat diperoleh perusahaan untuk tiap rupiah modal kerja. Formulasi dari Working Capital Turnover (WCT) adalah sebagai berikut (Sawir, 2001: 16) :

$$
W T C=\frac{\text { Penjualan }}{\text { Aktiva Lancar }- \text { Utang Lancar }} X 100 \%
$$

\section{Likuiditas}

Rasio likuiditas menurut Fred Weston yang dikutip oleh Kasmir (2010:129) menyatakan bahwa, " rasio likuiditas (liquiditiy ratio) merupakan rasio yang menggambarkan kemampuan 
perusahaan dalam memenuhi kewajiban (utang) jangka pendek." Untuk menilai likuiditas perusahaan dapat digunakan Current Ratio. Current Ratio menurut Van Horne (2009:206) adalah " rasio yang menunjukkan kemampuan perusahaan untuk membayar kewajiban jangka pendeknya dengan menggunakan aktiva lancarnya." Formulasi untuk mengetahui rasio ini sebagai berikut (Van Horne, 2009:206):

\section{Solvabilitas}

$$
\text { Current Ratio }=\frac{\text { Aktiva Lancar }}{\text { Kewajiban Lancar }} X 100 \%
$$

Menurut Kasmir (2010:151), rasio solvabilitas (leverage ratio) adalah "rasio yang digunakan untuk mengukur sejauh mana aktiva perusahaan dibiayai dengan utang." Untuk menilai solvabilitas perusahaan dapat menggunakan Debt to Equity Ratio. Debt to Equity Ratio adalah rasio utang terhadap ekuitas. Dimana rasio ini digunakan untuk menilai utang dengan ekuitas. Formulasi untuk mencari rasio Debt to Equity Ratio sebagai berikut (Kasmir, 2010:158) :

\section{Profitabilitas}

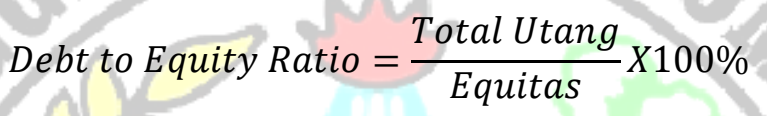

Rasio profitabilitas menurut Kasmir (2010:196) "merupakan rasio untuk menilai kemampuan perusahaan dalam mencari keuntungan". Rasio ini dapat dilakukan dengan membandingkan berbagai komponen yang ada di laporan keuangan, terutama neraca dan laporan laba rugi. Tujuannya untuk melihat perkembangan perusahaan dalam rentang waktu tertentu, baik penurunan atau kenaikan. Untuk mengukur tingkat profitabilitas dapat menggunakan Return on Investment. Return on Investment adalah rasio yang menunjukkan hasil (return) atas jumlah aktiva yang digunakan dalam perusahaan. Formula untuk mencari return on investment dapat digunakan sebagai berikut (Kasmir, 2010:202) :

$$
R O I=\frac{\text { Laba Setelah Bunga dan Pajak }}{\text { Total Aktiva }} \times 100 \%
$$

\section{Pengaruh Variabel Independen Terhadap Variabel Dependen Pengaruh Efisiensi Modal Kerja Terhadap Profitabilitas}

Efisiensi modal kerja dapat dinilai dengan menggunakan rasio antara total penjualan dengan jumlah modal kerja rata-rata yang sering disebut working capital turnover (perputaran modal kerja). Rasio ini menunjukkan hubungan antara modal kerja dengan penjualan yang dapat diperoleh perusahaan untuk tiap rupiah modal kerja. Perputaran modal kerja akan berpengaruh kepada tingkat profitabilitas. Dari uraian di atas, dapat ditarik sebuah hipotesis sebagai berikut:

$\mathrm{H} 1$ = Perputaran modal kerja (working capital turnover) berpengaruh positif terhadap profitabilitas

\section{Pengaruh Likuiditas Terhadap Profitabilitas}

Rasio lancar merupakan rasio yang digunakan untuk mengukur seberapa besar likuiditas perusahaan. Rasio lancar merupakan perbandingan antara aktiva lancar dengan hutang lancar. Rasio ini dapat menunjukkan kemampuan perusahaan untuk membayar kewajiban jangka pendeknya (Horne dan Wachowicz, 2009). Dari uraian diatas, dapat ditarik sebuah hipotesis sebagai berikut :

$\mathrm{H} 2=$ Current ratio berpengaruh negatif terhadap profitabilitas 


\section{Pengaruh Solvabilitas Terhadap Profitabilitas}

Menurut Kasmir (2010:151), rasio solvabilitas (leverage ratio) adalah "rasio yang digunakan untuk mengukur sejauh mana aktiva perusahaan dibiayai dengan utang." Rasio ini digunakan untuk mengukur kemampuan perusahaan untuk membayar seluruh kewajibannya, baik jangka pendek maupun jangka panjang apabila perusahaan dilikuidasi. Dari uraian diatas, dapat ditarik hipotesis sebagai berikut:

H3 = Debt to Equity Rasio berpengaruh positif terhadap profitabilitas

\section{METODE PENELITIAN}

Sumber data penelitian ini menggunakan data sekunder, yaitu sumber data penelitian yang diperoleh dari data berupa dokumen dan informasi tertulis yang berhubungan dengan objek penelitian yang diterbitkan oleh pihak lain, dalam hal ini pihak Bursa Efek Indonesia.

\section{Populasi dan Sampel}

Populasi dalam penelitian ini adalah seluruh perusahaan-perusahaan yang tergabung dalam kelompok saham BLUE CHIPS yang terdaftar pada Bursa Efek Indonesia dari tahun 2010 sampai dengan tahun 2015 yang memiliki laporan keuangan yang lengkap dan dipublikasikan dalam Indonesian Capital Market Directory (ICMD).

Pemilihan sampel dilakukan berdasarkan metode Purposive Sampling, yaitu pemilihan sampel saham perusahaan selama periode penelitian berdasarkan pertimbangan atau kriteria tertentu. Adapun tujuan dari metode ini untuk mendapatkan sampel yang reprensentatif sesuai dengan kriteria yang telah ditentukan.

Berdasarkan kriteria-kriteria atau pertimbangan yang telah ditetapkan dari tahun 2010 sampai dengan tahun 2015 terdapat 30 perusahaan-perusahaan yang tergabung dalam kelompok saham BLUE CHIPS yang terdaftar di Bursa Efek Indonesia. Dari seluruh populasi yang ada, sampel yang memenuhi kriteria yang telah ditentukan tersebut terdiri atas 13 sampel perusahaan.

\section{Definisi Operasional}

\section{Efisiensi Modal Kerja}

Efisiensi modal kerja adalah pemanfaatan modal kerja aktivitas operasional perusahaan secara optimal sehingga mampu meningkatkan kemakmuran perusahaan itu sendiri. Formulasi dari Working Capital Turnover (WCT) adalah sebagai berikut (Sawir, 2001: 16) :

\section{Likuiditas}

$$
W T C=\frac{\text { Penjualan }}{\text { Aktiva Lancar }- \text { Utang Lancar }} \times 100 \%
$$

Rasio likuiditas (liquiditiy ratio) merupakan rasio yang menggambarkan kemampuan perusahaan dalam memenuhi kewajiban (utang) jangka pendek. Formulasi untuk mengetahui rasio ini sebagai berikut (Van Horne, 2009:206):

$$
\text { Current Ratio }=\frac{\text { Aktiva Lancar }}{\text { Kewajiban Lancar }} X 100 \%
$$

\section{Solvabilitas}

Rasio solvabilitas (leverage ratio) adalah rasio yang digunakan untuk mengukur sejauh mana aktiva perusahaan dibiayai dengan utang. Formulasi untuk mencari rasio Debt to Equity Ratio sebagai berikut (Kasmir, 2010:158) : 


$$
\text { Debt to Equity Ratio }=\frac{\text { Total Utang }}{\text { Equitas }} X 100 \%
$$

\section{Profitabilitas}

Rasio profitabilitas merupakan rasio untuk menilai kemampuan perusahaan dalam mencari keuntungan. Formula untuk mencari return on investment dapat digunakan sebagai berikut (Kasmir, 2010:202) :

\section{Teknik Analisis Data}

$$
\text { ROI }=\frac{\text { Laba Setelah Bunga dan Pajak }}{\text { Total Aktiva }} X 100 \%
$$

\section{Analisis Regresi Linier Berganda}

Penelitian ini akan menggunakan metode Multiple Regression untuk analisis impact dari variabel independent terhadap variabel dependen. Model ini dipilih karena penelitian ini dirancang untuk menentukan variabel independent yang mempunyai pengaruh terhadap variabel dependent. Model yang dimaksud adalah sebagai berikut (Priyatno, 2010) :

$$
Y=\alpha+\beta_{1} X_{1}+\beta_{2} X_{2}+\beta_{3} X_{3}+e
$$

\section{Pengujian Hipotesis}

Pengujian hipotesis dilakukan melalui model regresi linier berganda. Tingkat signifikansi yang digunakan dalam penelitian ini adalah $\alpha=5 \%$.

\section{Koefisien Determinasi $\left(\mathbf{R}^{2}\right)$}

Koefisien Determinasi (R2) untuk mengukur seberapa jauh kemampuan model dalam menerangkan variabel dependen. Nilai Kd adalah antara 0 dan 1 . Nilai $\mathrm{R}$ yang kecil berarti kemampuan variabel-variabel Independen dalam menerangkan variabel dependen sangat terbatas. Nilai yang mendekati 1 berarti variabel independen memberikan hampir semua informasi yang dibutuhkan untuk memprediksi variasi variabel independen.

\section{Uji t Statistik}

Uji t digunakan untuk mengetahui apakah variabel independen secara parsial mempunyai pengaruh yang signifikan terhadap variabel dependen.

\section{Uji F Statistik}

Uji $F$ digunakan untuk menguji tingkat signifikansi koefisien regresi variabel independen secara serempak terhadap variabel dependen.

HASIL DAN PEMBAHASAN Analisis Regresi Linier Berganda

\begin{tabular}{|c|c|c|c|c|c|c|c|}
\hline \multirow[b]{2}{*}{ Model } & \multicolumn{2}{|c|}{$\begin{array}{c}\text { Unstandardized } \\
\text { Coefficients }\end{array}$} & \multirow{2}{*}{$\begin{array}{c}\begin{array}{c}\text { Standardized } \\
\text { Coefficients }\end{array} \\
\text { Beta }\end{array}$} & \multirow[b]{2}{*}{$\mathrm{t}$} & \multirow[b]{2}{*}{ Sig. } & \multicolumn{2}{|c|}{ Collinearity Statistics } \\
\hline & B & Std. Error & & & & Tolerance & VIF \\
\hline
\end{tabular}

Tabel 1 Analisis Regresi Linier Berganda

Coefficients ${ }^{\mathrm{a}}$ 


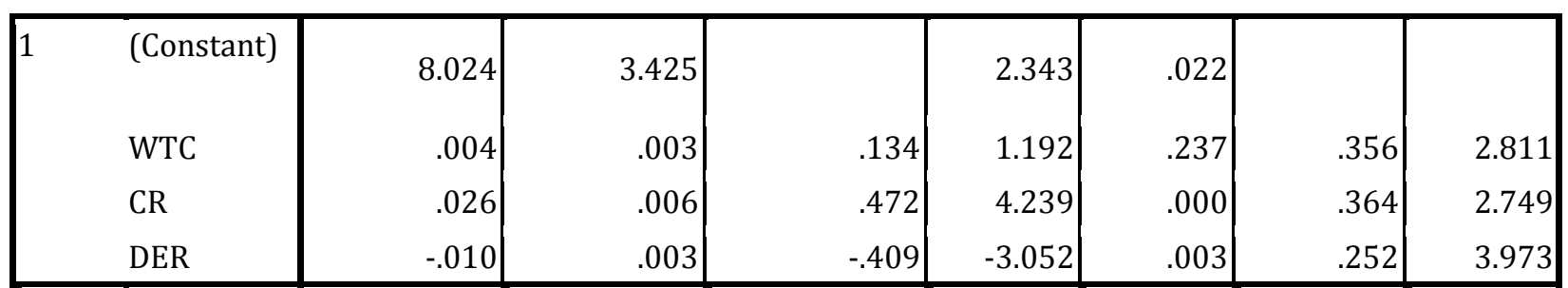

a. Dependent Variable: ROI

Berdasarkan tabel diatas, persamaan regresi linier berganda dalam penelitian ini adalah :

$$
\begin{gathered}
Y=\boldsymbol{\alpha}+\boldsymbol{\beta}_{1} \mathbf{X}_{1}+\boldsymbol{\beta}_{2} \mathbf{X}_{2}+\boldsymbol{\beta}_{3} \mathbf{X}_{3}+\boldsymbol{e} \\
Y=8,024+0,004 X_{1}+0,026 X_{2}-0,010 X_{3}+e
\end{gathered}
$$

Persamaan regresi di atas dapat dijelaskan sebagai berikut:

a. Konstanta sebesar 8,024; artinya apabila $\mathrm{X}_{1}, \mathrm{X}_{2}$, dan $\mathrm{X}_{3}$ nilainya 0 , maka nilai ROI-nya adalah 8,024 .

b. Koefisien regresi variabel X1 sebesar 0,004; artinya apabila X1 mengalami kenaikkan 1\%, maka nilai ROI akan mengalami kenaikan sebesar 0.004 dengan asumsi bahwa variabel independen lain nilainya tetap.

c. Koefisien regresi variabel X2 sebesar 0,026; artinya apabila X2 mengalami kenaikan $1 \%$, maka nilai ROI akan mengalami kenaikan sebesar 0,026 dengan asumsi variabel independen lain nilainya konstan.

d. Koefisien regresi variabel X3 sebesar - 0,010; artinya apabila X3 mengalami penurunan 1\%, maka nilai ROI akan mengalami penurunan sebesar 0,010 dengan asumsi variabel independen lain nilainya konstan.

\section{Pengujian Hipotesis}

\section{Koefisien Determinasi (R2)}

Tabel 2 Hasil Koefisien Determinasi (R2) Model Summaryb

\begin{tabular}{|l|r|r|r|r|r|}
\hline Model & R & R Square & $\begin{array}{c}\text { Adjusted R } \\
\text { Square }\end{array}$ & $\begin{array}{c}\text { Std. Error of } \\
\text { the Estimate }\end{array}$ & $\begin{array}{c}\text { Durbin- } \\
\text { Watson }\end{array}$ \\
\hline 1 & .816 & .666 & .652 & 4.76312 & 1.573 \\
\hline
\end{tabular}

a. Predictors: (Constant), DER, CR, WTC

b. Dependent Variable: ROI

Berdasarkan output diatas, diperoleh nilai $R$ square sebesar 0.816 atau $81.6 \%$. artinya semua variabel independen memiliki pengaruh sebesar $81.6 \%$ terhadap variabel dependen. Sisanya sebesar $18.4 \%$ dipengaruhi oleh variabel lain. Variabel yang mungkin berpengaruh terhadap variabel dependen (Return on Investment) adalah aktifitas dan pasar (Kasmir, 2010:151). Hal ini disebabkan karena kedua variabel tersebut memiliki korelasi yang besar terhadap profitabilitas. Jadi berdasarkan hal tersebut, kedua variabel diatas dianggap berada pada angka $18.4 \%$.

\section{Uji t Statistik}

Uji t (uji parsial) dilakukan untuk melihat secara individu pengaruh secara signifikan dari variabel independen terhadap variabel dependent.

Berdasarkan tabel diatas pada variabel WCT diperoleh nilai $t$ hitung sebesar 1.192, Sedangkan nilai t tabel sebesar 1.99167. Ini berarti bahwa t hitung < dari t tabel. Hal ini dapat 
disimpulkan bahwa efisiensi modal kerja tidak mempunyai pengaruh yang signifikan secara parsial terhadap profitabilitas.

Berdasarkan tabel diatas pada variabel CR diperoleh nilai t hitung sebesar 4.239, Sedangkan nilai t table sebesar 1.99167. Ini berarti bahwa t hitung > dari t table. Hal ini dapat disimpulkan bahwa likuiditas mempunyai pengaruh yang signifikan secara parsial terhadap profitabilitas.

Berdasarkan tabel diatas pada variabel DER diperoleh t hitung sebesar -3.052, Sedangkan nilai $t$ table sebesar 1.99167. ini berarti bahwa t hitung > dari t table. Hal ini dapat disimpulkan bahwa solvabilitas mempunyai pengaruh yang signifikan secara parsial terhadap profitabilitas.

\section{Uji F Statistik}

\section{Tabel 3. Hasil Uji F Statistik}

\section{ANOVA}

\begin{tabular}{|c|c|c|c|c|c|c|}
\hline \multicolumn{2}{|c|}{ Model } & Sum of Squares & $\mathrm{df}$ & Mean Square & $\mathrm{F}$ & Sig. \\
\hline \multirow[t]{4}{*}{1} & Regression & & & & & \\
\hline & & 3346.432 & 3 & 1115.477 & 49.167 & $.000^{\mathrm{a}}$ \\
\hline & Residual & 1678.861 & 74 & 22.687 & & \\
\hline & Total & 5025.293 & 77 & & & \\
\hline
\end{tabular}

a. Predictors: (Constant), DER, CR, WTC

b. Dependent Variable: ROI

Uji F (uji serentak) dilakukan untuk melihat secara bersama-sama pengaruh secara signifikan dari variabel independent terhadap variabel.

Berdasarkan tabel diatas diperoleh nilai $F$ hitung sebesar 49.167. Sedangkan $F$ table sebesar 2.73. Ini berarti bahwa $\mathrm{F}$ hitung $>$ dari $\mathrm{F}$ table. Hal ini dapat disimpulkan bahwa efisiensi modal kerja, likuiditas dan solvabilitas secara bersama-sama mempunyai pengaruh yang signifikan terhadap profitabilitas. 


\section{PEMBAHASAN}

Berdasarkan hasil analisis data menunjukkan bahwa secara parsial efisiensi modal kerja (Working Capital Turnover) tidak berpengaruh signifikan terhadap profitabilitas. Hal ini menunjukkan bahwa perubahan modal kerja tidak berdampak pada perubahan profitabilitas. Perusahaan lebih banyak mendapatkan hutang. Hutang yang tinggi tidak selamanya menunjukkan itu jelek karena kreditur tidak akan sembarangan menanamkan modalnya, hal ini berarti perusahaan mendapatkan kepercayaan dari kreditur yang yakin akan kemampuan perusahaan untuk membayar hutang-hutangnya. Perusahaan lebih banyak menginvestasikan ke pos aktiva tetap (fix assets) untuk menghadapi persaingan di dunia bisnis yang semakin ketat. Tentu saja investasi ke pos aktiva tetap ini akan menurunkan tingkat profitabilitas perusahaan, dikarenakan aktiva tetap membutuhkan waktu yang lama atau tidak sebentar untuk membuahkan hasil.

Berdasarkan hasil analisis data menunjukkan bahwa secara parsial likuiditas (current ratio) berpengaruh signifikan terhadap profitabilitas (return on investment). Selain itu, dari hasil analisis regresi diperoleh koefisien $\beta$ yang bertanda positif, yang berarti setiap terjadi kenaikan pada current ratio (CR) maka akan meningkatkan return on investment (ROI). Van Horne dan Wachowicz (2012:262) menyatakan jika perusahaan memutuskan menetapkan modal kerja dalam jumlah yang besar, maka semakin besar juga tingkat likuiditas perusahaan, jika hal-hal lainnya sama. Dengan tingkat likuiditas yang lebih besar, maka risiko semakin kecil, namun kesempatan untuk memperoleh laba yang besar akan menurun yang pada akhirnya berdampak pada menurunnya profitabilitas. Current Ratio menurut Van Horne (2009:206) adalah "rasio yang menunjukkan kemampuan perusahaan untuk membayar kewajiban jangka pendeknya dengan menggunakan aktiva lancarnya." Makin tinggi likuiditas, maka makin baiklah posisi perusahaan di mata kreditur. Oleh karena terdapat kemungkinan yang lebih besar bahwa perusahaan akan dapat membayar kewajibannya tepat pada waktunya.

Berdasarkan hasil analisis data menunjukkan bahwa secara parsial Solvabilitas (Debt to Equity Ratio) berpengaruh signifikan terhadap profitabilitas (return on investment), tetapi memiliki pengaruh yang negative terhadap return on invesment. Hal ini mengindikasikan bahwa hutang jangka panjang akan berbanding lurus dengan keuntungan. Ini sesuai dengan teori yang diungkapkan oleh Riyanto (1995) yang menyatakan bahwa semkin tingggi return on investmen maka akan menurunkan debt equity ratio, karena debt equity ratio menggambarkan kemampuan perusahaan dalam membayar hutang.

Berdasarkan hasil analisis data menunjukkan bahwa secara simultan efisiensi modal kerja, likuiditas dan solvabilitas berpengaruh secara simultan terhadap profitabilitas. Hal ini mengidentifikasikan bahwa secara bersama-sama atau serempak ketiga variabel independen (Efisiensi Modal Kerja, Likiuditas dan Solvabilitas) tersebut perpengaruh terhadap profitabilitas.

\section{PENUTUP}

\section{Simpulan}

Berdasarkan hasil analisis dan pembahasan dalam penelitian ini dapat disimpulkan bahwa:

1. Efisiensi modal kerja tidak mempunyai pengaruh yang signifikan secara parsial terhadap profitabilitas pada perusahaan-perusahaan yang terdaftar di Bursa Efek Indonesia periode 2010-2015.

2. Likuiditas mempunyai pengaruh yang signifikan secara parsial terhadap profitabilitas pada perusahaan-perusahaan yang terdaftar di Bursa Efek Indonesia periode 2010-2015.

3. Solvabilitas mempunyai pengaruh yang signifikan secara parsial terhadap profitabilitas pada perusahaan-perusahaan yang terdaftar di Bursa Efek Indonesia periode 2010-2015.

4. Efisiensi modal kerja, likuiditas dan solvabilitas secara bersama-sama mempunyai pengaruh yang signifikan terhadap profitabilitas pada perusahaan-perusahaan yang terdaftar di Bursa Efek Indonesia periode 2010-2015.

\section{Saran}


Berdasarkan kesimpulan diatas maka saran yang dapat diberikan adalah sebagai berikut :

1. Perusahaan sebaiknya meningkatkan pengelolaan modal kerjanya secara efisien dan menekan beban pokok penjualan. Sehingga perusahaan mampu mencapai keuntungan yang diinginkan serta mampu meningkatkan profitabilitas secara signifikan.

2. Perusahaan harus dapat mempertahankan dan menjaga tingkat likuiditas dengan baik. Semakin tinggi tingkat likuiditas, risiko semakin kecil, hal ini menunjukkan semakin baiklah posisi perusahaan di mata kreditur.

3. Perusahaan harus memperhatikan tingkat solvabilitasnya. Perusahaan dapat meningkatkan porsi sumber pendanaan melalui hutang jika perusahaan dapat mengelola sumber dana yang berasal dari hutang dengan baik dan digunakan untuk proyek investasi yang produktif, sehingga dapat memberikan pengaruh yang positif dan berdampak terhadap peningkatan profitabilitas perusahaan.

4. Untuk peneliti selanjutnya diharapkan dapat menambah jumlah variabel independen lain, sektor industri lain dan memperpanjang periode penelitian.

\section{DAFTAR RUJUKAN}

Agnes Sawir, (2001). Analisis Kinerja Keuangan dan Perencanaan Keuangan Perusahaan. Jakarta: PT Gramedia Pustaka Utama.

Brigham, F. Eugene, dan Houston, F. Joel. 2001. Manajemen Keuangan. Jakarta: Erlangga.

C. Handoyo Wibisono. 1997. Manajemen Modal Kerja. Andi Offset : Yogyakarta.

Hanafi, M. Mamduh dan Halim, Abdul. 2005. Analisis Laporan Keuangan. Yogyakarta: AMP-YKPN.

Indonesian Capital Market Directory (ICMD) 2010-2015. Bursa Efek Indonesia.

Kasmir. 2010. Analisis Laporan Keuangan, Edisi Ketiga. Jakarta: Rajawali Pers.

Priyatno, Duwi. 2010. Paham Analisa Statistik Data dengan SPSS. MediaKom: Jakarta

Sugiyono. 2010. Metode Penelitian Kuantitatif Kualitatif dan R\&D. Bandung: Alfabeta.

Syamsuddin, Lukman. 2007. Manajemen keuangan perusahaan. Jakarta : Raja Grafindo Persada.

Van Horne, James C dkk. 2009. Prinsip-prinsip Manajemen Keuangan. Edisi keduabelas buku 1. Jakarta: Salemba Empat. 